\title{
Deteksi Kerusakan Perkotaan Akibat Gempa Bumi Di Kota Palu Menggunakan Data Satelit Sentinel-1
}

\author{
Muhammad Faisal Bashiir \\ Teknologi Geomatika, Politeknik Pertanian Negeri \\ Samarinda, Samarinda, 75131 \\ faisalbashiir11@gmail.com
}

\author{
Nia Kurniadin* \\ Teknologi Geomatika, Politeknik Pertanian Negeri \\ Samarinda, Samarinda, 75131 \\ niakurniadin@politanisamarinda.ac.id \\ *Corresponding author
}

\begin{abstract}
Abstrak-Gempa bumi dan Tsunami melanda Kota Palu pada tanggal 28 september 2018. Gempa bermagnitudo 7,4 mengguncang Kota Palu dan Donggala. Pusat gempa berada pada kedalaman $10 \mathrm{~km}$ di $27 \mathrm{~km}$ sebelah timur laut Donggala mengakibatkan tsunami setinggi hampir 6 meter dengan kecepatan $800 \mathrm{~km} / \mathrm{jam}$ menerjang Pantai Talise dan Likuifaksi di Kelurahan Petobo dan Balaroa. Akibat bencana tersebut terjadi kerusakan beberapa bangunan penting seperti Hotel, Pusat Perbelanjaan, Gedung Pemerintahan, dan Sarana Pendidikan serta ratusan rumah rusak parah bahkan hilang akibat likuifaksi. Penelitian ini bertujuan untuk mendeteksi kerusakan perkotaan akibat gempa bumi di kota palu menggunakan data Sentinel-1. Softwere ESA SNAP digunakan untuk mengolah data Sentinel-1. Data yang telah dioleh selanjutnya dianalsis untuk mendeteksi kerusakan yang terjadi setelah gempa yang melanda Kota Palu. Hasil penelitian menunjukkan bahwa data Sentinel1 ini dapat mendeteksi kerusakan bangunan akibat gempa bumi di Kota Palu, namun pada Kelurahan Petobo Kecamatan Palu Selatan dan Kelurahan Balaroa Kecamatan Palu Barat yang mengalami Likuifaksi tidak terdeteksi kerusakan bangunannya secara signifikan. Luasan kerusakan yang terdeteksi adalah pada kecamatan Mantikulore 89,913 Ha, Palu Barat 10,893 Ha, Palu Selatan 10,285 Ha, Palu Timur 13,142 Ha, Palu Utara 4,568 Ha, Tatanga 7,553 Ha, Taweli 9,082 Ha, dan Ulujadi 117,251 Ha.
\end{abstract}

Kata Kunci-Gempa Bumi, Likuifaksi, Kota Palu, Synthetic Aperture Radar, Sentinel-1, ESA SNAP

\section{Pendahuluan}

Pada tanggal 28 september 2018 telah terjadi bencana alam yaitu gempa bumi dan tsunami yang melanda Kota Palu. Menurut Welianto (2020), bencana adalah peristiwa yang mengancam dan mengganggu kehidupan yang disebabkan baik oleh faktor alam, non alam maupun faktor manusia dan menimbulkan korban jiwa manusia, kerusakan lingkungan, kerugian harta benda, dan psikologi.

Gempa bermagnitudo 7,4 mengguncang Kota Palu dan Donggala. Pusat gempa pada kedalaman $10 \mathrm{~km}$, berada di $27 \mathrm{~km}$ sebelah timur laut Donggala mengakibatkan tsunami setinggi hampir 6 meter dengan kecepatan 800 $\mathrm{km} / \mathrm{jam}$ menerjang Pantai Talise dan Likuifaksi di Kelurahan Petobo dan Balaroa. Akibat bencana tersebut terjadi kerusakan beberapa bangunan penting seperti Hotel, Pusat Perbelanjaan, Gedung Pemerintahan, dan Sarana Pendidikan serta ratusan rumah rusak parah bahkan hilang akibat likuifaksi yang terjadi di Kelurahan Petobo dan Balaroa.

Untuk mengetahui dampak yang diakibatkan oleh bencana alam gempa bumi dan tsunami serta likuifaksi yang terjadi di Kota Palu, yang mengakibatkan banyaknya kerusakan yang terjadi seperti kerusakan bangunan dan fasilitas umum, penulis memandang perlu melakukan tinjauan menggunakan teknologi penginderaan jauh dengan memenfaatkan data citra satelit. Beberapa penelitian tentang pemanfaatan teknologi penginderaan jauh menggunakan data multispektral seperti landsat-8 yang dilakukan oleh Fadlin dkk. (2020), untuk mendeteksi indeks kekritisan lingkungan maupun sentinel-2 telah dilakukan. Data Sentinel-1 digunakan dalam penelitian ini. Satelit Sentinel-1 membawa sensor SAR untuk merekam permukaan bumi dengan menggunakan C-band beroperasi pada frekuensi $5,405 \mathrm{~Hz}$ yang dapat menembus awan dan hujan sehingga hasil perekamannya bebas dari gangguan cuaca dan dapat beroperasi siang dan malam. Dari data citra satelit ini diharapkan dapat dilakuan analisis untuk mendeteksi kerusakan perkotaan akibat gempa bumi di kota palu.

\section{STUDI PUSTAKA}

Penginderaan jauh adalah ilmu yang mempelajari pengambilan informasi tentang permukaan bumi, darat dan laut, dari citra yang diperoleh dari jarak jauh. Metode ini biasanya tergantung pada pengukuran energi elektromagnetik yang dipantulkan atau dipancarkan oleh objek yang diamati (Campbell, 1987).

SAR merupakan salah satu teknik penginderaan jauh sensor aktif yang menggunakan gelombang mikro dari spektrum elektromagnetik. SAR adalah salah satu sistem kerja dari radar yang berupaya untuk meningkatkan resolusi citra RADAR. Teknik yang digunakan adalah dengan memasang antena jamak (Septiana dkk., 2017). 
Sistem SAR terdiri dari pemancar, antenna penerima dan sistem elektronik yang digunakan untuk merekam data. Pemancar mengirimkan pulsa gelombang mikro secara kontinyu dan terfokus ke permukaan bumi, kemudian energi yang sampai ke permukaan bumi akan dihambur balikkan dan diterima oleh antena penerima untuk kemudian direkam. SAR merupakan sensor aktif yang berarti SAR memancarkan energi sendiri tanpa tergantung energi dari matahari, sehingga SAR bisa dioperasikan pada siang ataupun malam bisa digunakan dalam segala kondisi cuaca karena panjang gelombang mikro dapat menembus awan, hujan, dan asap. Radar sensitif terhadap kekasaran permukaan yang disinari. Informasi citra SAR ini dapat dipakai sebagai komplemen satu sama lain dengan citra optis (Sambodo \& Musyarofah, 2011).

Sutanto (1987) dalam Bayanuddin \& Anna (2016), menyatakan bahwa penggunaan panjang gelombang radar tergantung dari aplikasinya terutama karena memiliki kemampuan penetrasi yang berbeda-beda pada objek tertentu. Citra radar saluran X, C, dan L banyak digunakan di daerah tropik yang selalu tertutup awan dan sering menjadi data tunggal untuk beberapa daerah dengan karaketristik semacam ini, Satelit Sentinel-1 membawa sensor SAR untuk merekam permukaan bumi dengan menggunakan C-band beroperasi pada frekuensi $5,405 \mathrm{~Hz}$ yang dapat menembus awan dan hujan sehingga hasil perekamannya bebas dari gangguan cuaca dan dapat beroperasi siang dan malam sehingga baik digunakan untuk berbagai aplikasi di Indonesia yang mana data citra optik sering tertutupi oleh awan.

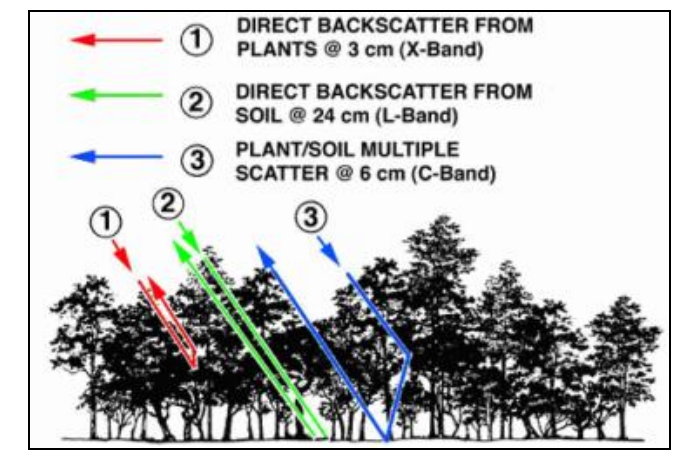

Gambar 1. Daya Tembus Gelombang Radar Pada Vegetasi.

Daya tembus sinyal SAR terhadap vegetasi juga dipengaruhi oleh panjang gelombang dan struktur kanopi. Kemampuan penetrasi band-C pada kanopi pohon merupakan keunggulan dari data SAR Sentinel-1 dibanding data optis sehingga parameter fisik biomassa (dbh/diameter at breast height dan tinggi pohon) untuk dapat terdeteksi lebih baik.

Sentinel-1 merupakan seri satelit pertama dari tujuh misi satelit yang diluncurkan sebagai bagian dari program Copernicus yang digagas oleh European Commission (EC) dan European Space Agency (ESA). Seperti satelit SAR ESA sebelumnya, Sentinel-1 memiliki sensor Cband dengan dua buah satelit yakni Sentinel-1a dan Sentinel-1b yang mengorbit secara tandem berjauhan $180^{\circ}$. Masing-masing satelit mampu melakukan repeat cycle setiap 12 hari dan dengan konstelasi kedua satelit tersebut membuat Sentinel-1 memiliki repeat cycle setiap 6 hari. Sentinel-1 memiliki 4 mode pengamatan dengan mode utama di daratan adalah mode Interferometric Wide Swath (IW) dengan resolusi spasial sekitar $5 \mathrm{~m}$ x $20 \mathrm{~m}$ (Islam dkk., 2017).

\section{MetOdOLOGI}

\section{A. Lokasi Penelitian}

Objek penelitian ini adalah Kota Palu Provinsi Sulawesi Tengah, secara geografis terletak di antara 0 36' - 0 ${ }^{\circ} 56^{\prime}$ Lintang Selatan dan 119 $45^{\prime}$ - 120 01' Bujur Timur. Pemilihan lokasi penelitian berdasarkan hasil studi literatur dan analisis data historis bencana Gempa Bumi dan Tsunami yang terjadi pada tanggal 28 September 2018. Lokasi penelitian ditunjukkan pada Gambar 2 berikut:

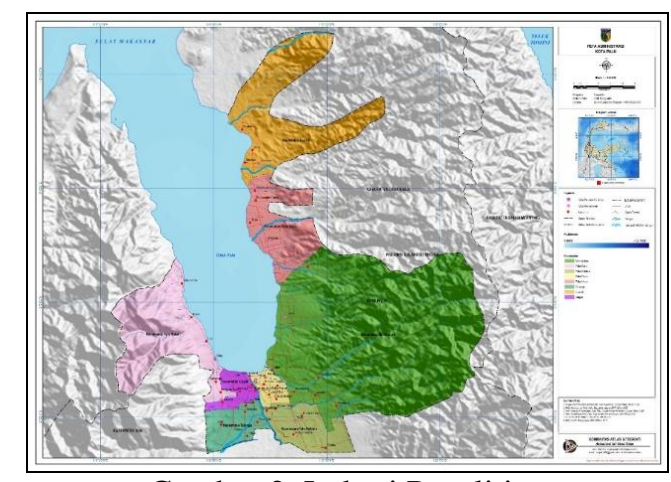

Gambar 2. Lokasi Penelitian

\section{B. Data dan Peralatan}

Data yang digunakan dalam penelitian ini adalah data citra satelit Sentinel-1 path/frame 134/595 tanggal 07 Juni 2018, path/frame 134/593 tanggal 05 Oktober 2018 dan data batas administrasi Kota Palu

Perangkat lunak yang digunakan dalam penelitian ini adalah ESA SNAP 7.0 untuk mengolah citra (kalibrasi radiometrik, koreksi geometric, dan lain-lain), dan QGIS 3.10 untuk konversi raster ke vektor, overlay dan pembuatan layout peta.

\section{Tahap Pengumpulan dan Pengolahan Data}

Pengumpulan data yang terdiri dari data batas administrasi Kota Palu dan citra Sentinel-1 path/frame 134/595 tanggal 07 Juni 2018, path/frame 134/593 tanggal 05 Oktober 2018 pada halaman https://search.asf.alaska.edu/\#/.

Pengolahan data menggunakan perangkat lunak ESA SNAP 7.0 terhadap data sebelum (07 Juni 2018) dan data sesudah (05 Oktober 2018), diawali dengan melakukan Subset untuk memfokuskan pada area yang diminati, dan memilih intensitas_VV untuk hasil yang lebih baik. Dilanjutkan dengan Apply Orbit File untuk menerapkan informasi geografis pada setiap piksel.

Kalibrasi Radiometrik dilakukan untuk memperbaiki nilai piksel agar sesuai dengan nilai yang sebenarnya dari 
kesalahan atmosfer. Selanjutnya noise yang melekat pada data radar dihilangkan dengan proses Speckle Filtering.

Koreksi Geometrik dilakukan untuk menghilangkan kesalahan geometrik berupa kesalahan bentuk, sudut dan arah. Untuk meregangkan histogram data ke skala yang mudah diatur dilakukan Conversion to $d B$.

Create Stack dilakukan untuk menggabungkan atau tumpang-susun data sebelum dan sesudah untuk membandingkan perbedaan antara keduanya. Proses Change Detection dijalankan untuk mendeteksi perubahan yang terjadi dari data sebelum dan sesudah.

Pengolahan data dilanjutkan dengan menggunakan perangkat lunak $Q G I S$ 3.10. Data perubahan yang terjadi hasil proses Change Detection pada perangkat lunak ESA SNAP selanjutnya divektorisasi untuk mempermudah dalam proses analisis dan pembuatan peta menggunakan menu Polygonise (Raster to Vector).

Hasil proses vektorisasi selanjutnya dioverlay (ditumpang-susun) dengan data batas admnistrasi Kota Palu, juga dapat dioverlay juga dengan base map Open Street Map yang dapat ditambahkan ke perangkat lunak QGIS untuk mengetahui letak dan objek apa saja yang mengalamai perubahan atau kerusakan.

Proses akhir dari kegiatan ini adalah pembuatan layout peta, untuk menyajikan hasil deteksi kerusakan perkotaan akibat gempa bumi di Kota Palu menggunakan data Sentinel-1.

\section{HASIL DAN PEMBAHASAN}

Pengolahan data citra Sentinel-1 perekaman tanggal 07 Juni 2018 dan 05 Oktober 2018 untuk mendeteksi perubahan atau kerusakan menggunakan perangkat lunak ESA SNAP yang selanjutnya divektorisasi dan dioverlay dengan batas administrasi Kota Palu menggunakan perangkat lunak QGIS diperoleh informasi perubahan hasil deteksi seperti yang disajikan pada Gambar 3 berikut:

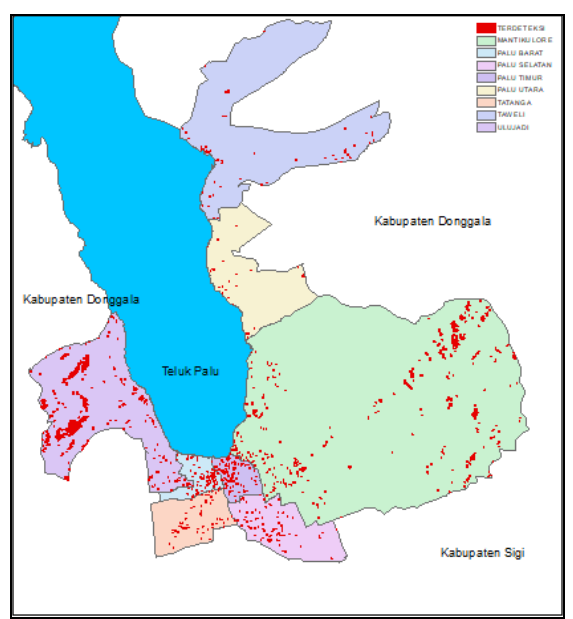

Gambar 3. Hasil Deteksi Kerusakan Perkotaan Akibat Gempa Bumi

Hasil pengolahan data Sentinel-1 dan overlay dengan batas administrasi dan peta dasar Open Street Map memberikan informasi bahwa data Sentinel-1 dapat memberikan petunjuk daerah mana saja yang mengalami kerusakan akibat gempa bumi di Kota Palu. Beberapa landmark yang mudah dikenali dideteksi mengalami kerusakan. Diantaranya adalah Masjid Baiturrahman di Jalan Pangeran Diponegoro (Samping Palu Grand Mall) dan Universitas Tadulako.

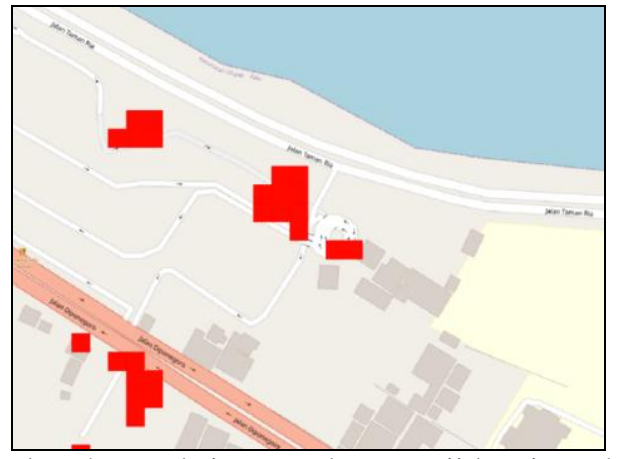

Gambar 4. Deteksi Kerusakan Masjid Baiturrahim

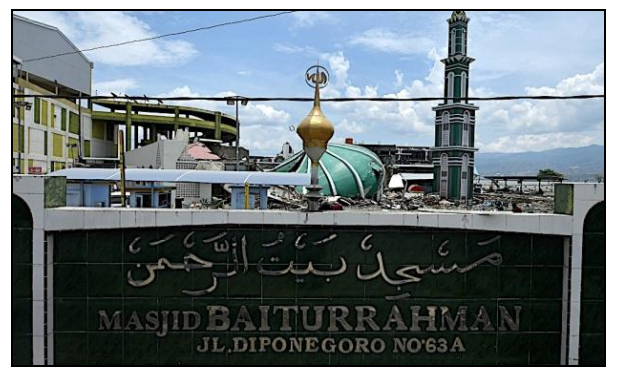

Gambar 5. Kondisi Masjid Baiturrahim

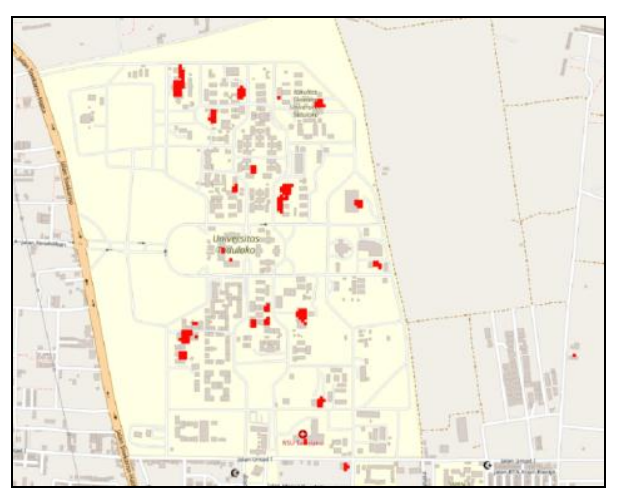

Gambar 6. Deteksi Kerusakan Universitas Tadulako

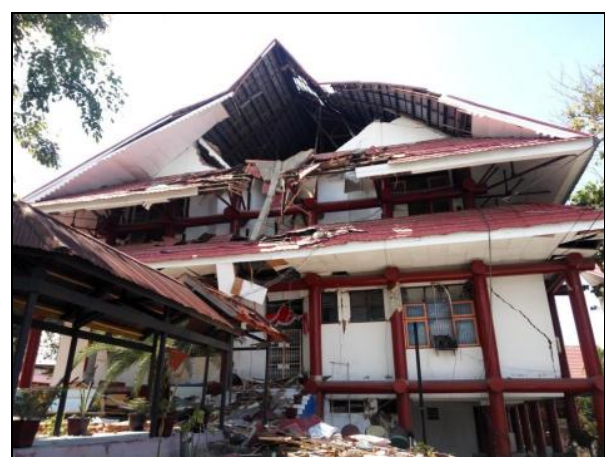

Gambar 7. Kondisi Salah Satu Bangunan Universitas Tadulako

Dari hasil deteksi kerusakan tersebut juga diperoleh informasi luasan kerusakan dari masing-masing kecamatan. Perubahan terluas terdeteksi di Kecamatan Ulujadi sebesar 117,251 Ha, dan perubahan terkecil terdeteksi di Kecamatan Palu Utara sebesar 4,568 Ha. 
Data kerusakan selengkapnya disajikan pada Tabel 1 berikut:

Tabel 1. Data Luasan Terdeteksi Kerusakan

\begin{tabular}{|c|l|c|}
\hline No & \multicolumn{1}{|c|}{ Kecamatan } & $\begin{array}{c}\text { Luasan Terdeteksi } \\
\text { Kerusakan (Ha) }\end{array}$ \\
\hline 1 & Mantikulore & 89,913 \\
\hline 2 & Palu Barat & 10,893 \\
\hline 3 & Palu Selatan & 10,285 \\
\hline 4 & Palu Timur & 13,142 \\
\hline 5 & Palu Utara & 4,568 \\
\hline 6 & Tatanga & 7,553 \\
\hline 7 & Tawaeli & 9,082 \\
\hline 8 & Ulujadi & 117,251 \\
\hline
\end{tabular}

Kerusakan terluas yang terjadi di Kecamatan Ulujadi berdasarkan data sekunder diperoleh informasi bahwa di kecamatan tersebut merupakan daerah pegunungan dengan kemiringan $15^{\circ}-40^{\circ}$ (BPS, 2015) yang dijadikan sebagai areal tambang galian $\mathrm{C}$ sehingga terjadi longsor pada saat terjadi gempa bumi (Perhatikan Gambar 8). Sedangkan di Kecamatan Palu Utara dengan kerusakan terkecil (4,568 Ha) disebabkan daerah landau dan pegunungan yang masih asli (tanpa tambang galian $\mathrm{C}$ ).

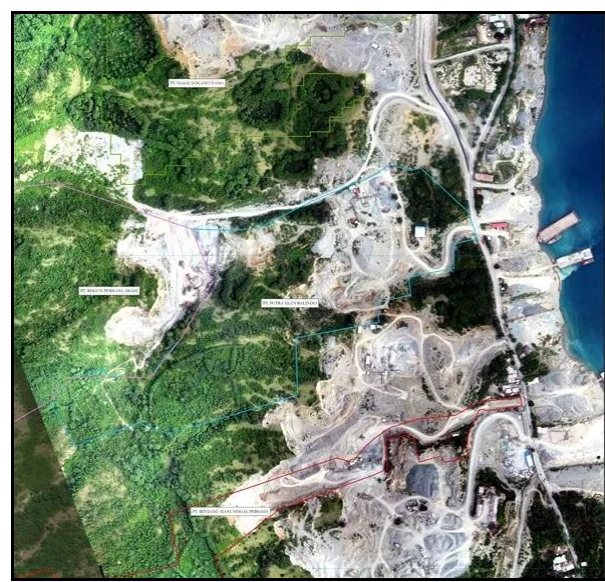

Gambar 8. Kondisi Tambang Galian C di Kecamatan Ulujadi

Berbeda halnya dengan beberapa landmark yang terdeteksi kerusakannya, citra Sentinel-1 tidak berhasil mendeteksi kerusakan yang diakibatkan oleh Likuifaksi di Kelurahan Petobo dan Balaroa. Pada kenyataannya kedua kelurahan tersebut mengalami kerusakan sangat parah. Sehingga perlu dilakukan kajian penginderaan jauh dengan citra Sentinel-1 yang lebih lanjut dalam hal metode yang digunakan untuk mendeteksi kerusakan akibat likuifaksi.

\section{KESIMPULAN}

Berdasarkan hasil penelitian yang telah dilaksanakan dapat disimpulkan bahwa data citra Sentinel-1 dapat mendeteksi kerusakan bangunan akibat gempa bumi yang terjadi di Kota Palu. Namun belum dapat memberikan informasi kerusakan yang diakibatkan oleh Likuifaksi yang terjadi di Kelurahan Petobo dan Kelurahan Balaroa secara signifikan, sehingga perlu dilakukan kajian penginderaan jauh dengan citra Sentinel-1 yang lebih lanjut dalam hal metode yang digunakan. Luasan kerusakan yang terdeteksi adalah pada kecamatan Mantikulore 89,913 Ha, Palu Barat 10,893 Ha, Palu Selatan 10,285 Ha, Palu Timur 13,142 Ha, Palu Utara 4,568 Ha, Tatanga 7,553 Ha, Taweli 9,082 Ha, dan Ulujadi 117,251 Ha.

\section{DAFTAR PUSTAKA}

Bayanuddin, A. A., \& Anna, A. N. (2016). Pendugaan Cadangan Karbon di Atas Permukaan Pada Hutan Rakyat dengan Memanfaatkan Data Synthetic Aperture Radar Sentinel-1 (Studi Kasus di Kabupaten Sukoharjo) [Universitas Muhammadiyah Surakarta]. http://eprints.ums.ac.id/47646/

BPS. (2015). Kota Palu dalam Angka. Badan Pusat Statistik.

Campbell, J. B. (1987). Introduction to Remote Sensing. The Guilford Press.

Fadlin, F., Kurniadin, N., \& Prasetya, F. V. A. S. (2020). Analisis Indeks Kekritisan Lingkungan di Kota Makassar Menggunakan Citra Satelit LANDSAT 8 OLI / TIRS. Jurnal Geodesi dan Geomatika (ELIPSOIDA), 03(01), 55-63.

Islam, L. J. F., Prasetyo, Y., \& Sudarsono, B. (2017). ANALISIS PENURUNAN MUKA TANAH (LAND SUBSIDENCE) KOTA SEMARANG MENGGUNAKAN CITRA SENTINEL-1 BERDASARKAN METODE DINSAR PADA PERANGKAT LUNAK SNAP. Jurnal Gedesi Undip, 6(2), 29-36.

Sambodo, K. A., \& Musyarofah. (2011). Perbandingan Operasi Direct Correlation dan Fast Fourier Transform pada Registrasi Citra untuk Pengolahan Awal Orthorektifikasi Data Synthetic Aperture Radar ( SAR ). Geomatika SAR Nasional, September, 223230.

Septiana, B., Wijaya, A. P., \& Suprayogi, A. (2017). Analisis Perbandingan Hasil Orthorektifikasi Metode Range Doppler Terrain Correction dan Metode SAR Simulation Terrain Correction Menggunakan Data SAR SENTINEL - 1. Jurnal Gedesi Undip, 6(1), $148-157$.

Welianto, A. (2020). Bencana Alam: Jenis, Penyebab dan Penanggulangannya.

Kompas.com. https://www.kompas.com/skola/read/2020/02/07/1600 00769/bencana-alam--jenis-penyebab-danpenanggulangannya?Page=all(banana. 